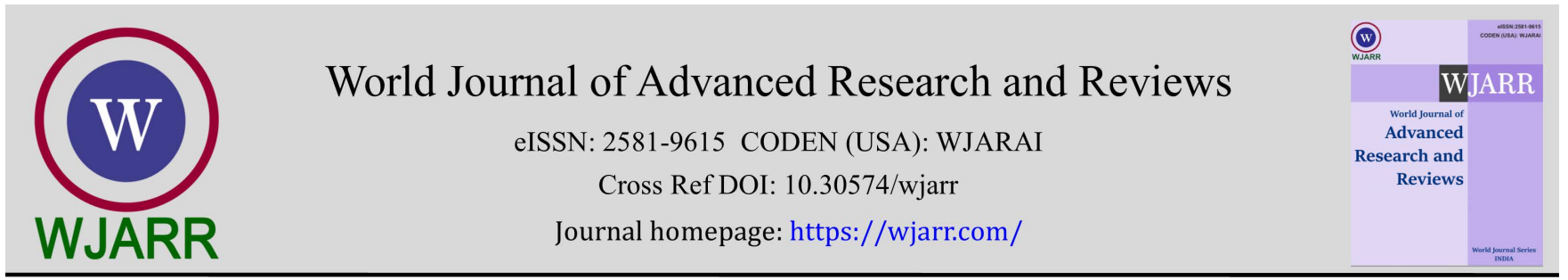

(RESEARCH ARTICLE)

\title{
The in vitro antisickling effect of purified alkaloids of Cremaspora triflora (Thonn.) K. Schum. (Rubiaceae) and Macaranga schweinfurthii Pax. (Euphorbiaceae)
}

Marsi Mbayo Kitambala 1, ${ }^{*}$, Emery Kalonda Mutombo 1, Blandine Nkiko Niyibizi 1, Grégoire Sangwa Kamulete 2, Glauber Mbayo Kalubandika 2, Jean Mulamba Muidikija ${ }^{3}$, Evodie Numbi wa Ilunga 2, Richard Muya Kalunga 2, Serge Mbuyi Kalonji 2, Welcome Muyumba Nonga 3,7, Nathalie Mwenze Musenge 2, James Maloba Mwinesenge 3, Faustin Mwamba Maseho 5, Albert Kanangila Bujitu 1, Pius Mpiana Tshimankinda ${ }^{6}$ and JeanBaptiste Lumbu Simbi ${ }^{1}$.

${ }^{1}$ Department of Chemistry, Faculty of Sciences, University of Lubumbashi, DR Congo.

${ }^{2}$ Faculty of Pharmaceutical Sciences, University of Lubumbashi, DR Congo.

${ }^{3}$ Department of Chemistry, Teacher's Training College of Mbuji-Mayi, Mbuji-Mayi, DR Congo.

${ }^{4}$ Department of Chemistry, Teacher's Training College of Lubumbashi, Lubumbashi, DR Congo.

${ }^{5}$ Faculty of Medicine, University of Kamina, Kamina, DR Congo.

${ }^{6}$ Department of Chemistry, University of Kinshasa, Kinshasa, RD Congo.

${ }^{7}$ Department of Therapeutic Chemistry and Pharmacognosy, University of Mons, Belgium.

World Journal of Advanced Research and Reviews, 2021, 09(03), 129-137

Publication history: Received on 04 February 2021; revised on 06 March 2021; accepted on 09 March 2021

Article DOI: https://doi.org/10.30574/wjarr.2021.9.3.0074

\begin{abstract}
Introduction and objective: Sickle cell disease is an inherited pathology to an abnormality of hemoglobin precisely hemoglobin $\mathrm{S}$ for which there is no curative therapy. It mainly affects sub-Saharan African and Caribbean populations. Thus, this study aims to make the phytochemical screening of Cremaspora triflora and Macaranga schweinfurthii as well as to evaluate the antisickling activity of their purified alkaloids.
\end{abstract}

Methodology: Chemical screening was performed using color and precipitation tests as well as the foam index method. The extraction of the alkaloids was carried out with organic solvents in a basic medium while the purification by open column chromatography. The evaluation of the antisickling activity was carried out by Emmel's test.

Results: The chemical screening highlighted alkaloids, steroids, saponins, tannins, and terpenoids in the species studied. Flavonoids and anthocyanins were present in organs of Macaranga schweinfurthii, but absent in Cremaspora triflora. The extraction showed that Macaranga schweinfurthii leaves contained $0.59 \%$ alkaloids and $0.73 \%$ alkaloids in Cremaspora triflora leaves. The alkaloids purification allowed to obtain an alkaloidal fraction MS1 (1.24 g, 70.05\%) from Macaranga schweinfurthii and two fractions [CT2 (0.934 g, 63.97\%) and CT3 (0.006 g, 0.41\%)] from Cremaspora triflora which tested positive with Dragendorff and Wagner reagents. The antisickling activity evaluation showed that the SIR varied between $36.00 \%(0.25 \mathrm{mg} / \mathrm{ml})$ and $90.66 \%(1 \mathrm{mg} / \mathrm{ml})$ for the alkaloid solutions of Cremaspora triflora (IC 50 of $0.51 \mathrm{mg} / \mathrm{ml})$ as well as between $4.00 \%(0.25 \mathrm{mg} / \mathrm{ml})$ and $33.33 \%(1 \mathrm{mg} / \mathrm{ml})$ for the alkaloid solutions of Macaranga schweinfurthii ( $\mathrm{IC}_{50}$ of $1.40 \mathrm{mg} / \mathrm{ml}$ ).

Conclusion: This study showed that the purified alkaloids of the studied plant species have an inhibitory power on sickling.

Keywords: Chemical screening; alkaloid; Antisickling; Euphorbiaceae; Rubiaceae

\footnotetext{
* Corresponding author: Mbayo Kitambala Marsi

Department of Chemistry, Faculty of Sciences, University of Lubumbashi, DR Congo.

Copyright $(2021$ Author(s) retain the copyright of this article. This article is published under the terms of the Creative Commons Attribution Liscense 4.0.
} 


\section{Introduction}

Sickle cell disease is a hereditary pathology mainly affecting populations of Central, and West Africa, Asia, the USA, the Caribbean region, and the Mediterranean region, in particular the Greeks, and Italians [1]. It is an inherited autosomal recessive genetic disease linked to an abnormal structure of hemoglobin leading to the formation of hemoglobin S ( $\mathrm{HbS}$ ). The disease systematically affects children who inherit the same mutant gene from their parents at birth. For a child with both parents who are carriers, the probability of inheriting both characteristic genes and having the disease is $25 \%$ and the probability of being a carrier is 50\%. Most carriers are in good health and lead normal lives.

The modes of treatment envisaged for this pathology to relieve the patients are in particular the medullary transplant of the marrow, the repeated blood transfusion, or the taking of hydroxyurea, a molecule which would activate the genes of fetal hemoglobin (HbF) whose presence in the erythrocyte interferes with the polymerization of hemoglobin $\mathrm{S}[2,3,4]$. Local populations cannot afford such treatments. This is how the majority of the population resort to the use of medicinal plants. Indeed, herbal medicine is currently presented as an alternative that can offer relief to sickle cell disease and its action on the body depends on the composition of the plants. Several plants are reported to be used for the treatment of sickle cell disease $[5,6,7]$. Medicinal plants can contain a wide variety of bioactive substances such as alkaloids, flavonoids, saponins, steroids, terpenoids, anthocyanins, and quinones which are endowed with several biological activities $[8,9]$.

Several studies on antisickling activity showed that polyphenols (anthocyanins, flavonoids) can normalize sickle cells in vitro $[3,10-14]$. Besides, other studies showed that several other natural substances are antisickling agents. These include phenylalanine, p-hydroxybenzoic acid and its derivatives, maslinic, oleanolic, and betulinic acids [15], limonoid [16], cepharantine [17], saponins [18], and alkaloids [19, 20].

Thus, this study will proceed to the phytochemical screening of harvested organs of Cremaspora triflora (Thonn.) K.Schum. (Rubiaceae), and Macaranga schweinfurthii Pax. (Euphorbiaceae), to extract and purify their alkaloids and to evaluate the antisickling activity of the purified alkaloids of these two species.

\section{Material and methods}

\section{$2.1 \quad$ Plant material}

The plant material consisted of the leaves, stems or their bark and roots, or their bark of $C$. triflora [Mubaba wanika (Bemba, Lala, and Lamba)], and M. schweinfurthii [Munkala (Luba), and Kilongalong (Lunda)]. These two species were collected in the forest gallery of the Kafubu River on the Sambwa side. The identification of the studied species was carried out by comparison with the reference herbaria at INERA-Kipopo. The harvested organs were dried out of direct sunlight at the Department of Chemistry of the Faculty of Sciences of the University of Lubumbashi. They were then crushed, reduced to a coarse powder, and then stored in plastic packaging.

\subsection{Biological material}

Blood was collected with the informed consent of the patient, and his parents whose SS sickle cell disease was confirmed by electrophoresis. This 5-year-old patient was not transfused or treated with hydroxyurea during the six months before the blood collection. After collection, the blood was kept in the fridge (Samsung brand, made in South Korea) at $4^{\circ} \mathrm{C}$. The sample was taken from the patient's elbow crease and blood was collected in the EDTA tube [21].

\subsection{Phytochemical screening}

The highlighting of chemical substance groups in solution is based on coloring reactions (due to complexation by charge transfer), precipitation (by phase separation), and formation of foams. These techniques concerned the search of alkaloids, flavonoids, anthocyanins, quinones, saponins, tannins, steroids, and terpenoids found in organs of the species studied [22-27].

\subsection{Extraction of alkaloids and their purification}

$200 \mathrm{~g}$ of ground material was macerated in $200 \mathrm{ml}$ of methanol in an Erlen meyer flask for 24 hours. The solution obtained was filtered and then concentrated to dryness at a rotary evaporator. The crude extract obtained after evaporation was taken up in $400 \mathrm{ml}$ of $1 \% \mathrm{HCl}$ (Sigma-Aldrich, Saint-Quentin Fallavier, France) and filtered through filter paper; the filtrate was basified with $20 \mathrm{ml}$ of $\mathrm{NH}_{4} \mathrm{OH}$ (Sigma-Aldrich, Saint-Quentin Fallavier, France) to reach a $\mathrm{pH}$ of 9. The alkaloids were then extracted thrice with $200 \mathrm{ml}$ of chloroform (Sigma-Aldrich, Saint-Quentin Fallavier, 
France) in a separatory funnel. After complete depletion of the alkaloids, the settled organic phase was filtered through filter paper, then evaporated in a rotary evaporator (Büchi brand, manufactured in Flawil, Swisse). This solution was then taken up twice in $200 \mathrm{ml}$ of $0.5 \mathrm{M}$ citric acid (Sigma-Aldrich, Saint-Quentin Fallavier, France) and then basified with $10 \mathrm{ml}$ of $12 \% \mathrm{NH}_{4} \mathrm{OH}$ and extracted four times with $50 \mathrm{ml}$ of chloroform. Chloroformed phases were combined, and filtered through filter paper (Whatman brand) wet with chloroform. The evaporation of the solvent to dryness at reduced pressure provided the extract of total alkaloids [28, 29].

The total alkaloid extracts chromatographed on an open column of silica gel $60 \mathrm{~F}_{254}$ were successively eluted in stepgradient mode using AcOEt-MeOH as mobile phase (100: 0, 90:10, 80:20, 70:30, 60:40, 0:100 v/v). The different fractions were subjected to thin-layer chromatography (TLC) on aluminum plates using as mobile phase AcOEt-MeOH$\mathrm{NH}_{4} \mathrm{OH}$ (90: 9.5: 0.5, v/v/v), and TLC plates were sprayed with Dragendorff's, Wagner's, and iodine reagents. The fractions with identical profiles were combined, evaporated at $30-40{ }^{\circ} \mathrm{C}$ to dryness and then stored in the fridge at $4{ }^{\circ} \mathrm{C}$ before carrying out the biological tests.

\section{$2.5 \quad$ Emmel's test}

\subsubsection{Preparation of solutions}

Weigh $1 \mathrm{mg}$ of the dry sample (Purified alkaloids); Dissolve it beforehand in a few drops of DMSO later in $1 \mathrm{ml}$ of physiological water to have an initial concentration of $1 \mathrm{mg} / \mathrm{ml}$. Diluted the main solution to get solutions of $0.5 \mathrm{mg} / \mathrm{ml}$, and $0.25 \mathrm{mg} / \mathrm{ml}$ respectively.

The control was prepared by mixing a drop of sickle cell blood, and a drop of physiological solution ( $0.9 \% \mathrm{NaCl})$. This preparation was incubated for 24 hours and then observed on an optical microscope (Brand Nikon Eclipse E200, Melville, NY, USA) after incubation in 5 fields.

\subsubsection{Assessment of antisickling activity in vitro}

A drop of blood placed on a slide was mixed with a drop of the alkaloid extract. The solution obtained was protected by a coverslip and sealed with molten paraffin for a microscopic preparation. After incubation for $24 \mathrm{~h}$ in a water bath at $37^{\circ} \mathrm{C}$, the preparations are examined under a digital optical microscope (Brand Nikon Eclipse E200, Melville, NY, USA). The images were observed in 5 different fields (on the left, on the right in the center, above, and below) by the same observer. The sickle cell inhibition rate or sickle cell preservation rate was calculated by the following formula:

$\operatorname{SIR}(\%)=\frac{(N S C B T-N S C A T) \times 100}{N S C B T}$

With NSCBT: Number of Sickle cells before treatment with the extract; NSCAT: Number of sickle cells after treatment with the extract; SIR: Sickle cell Inhibition Rate.

\section{Results}

\subsection{Phytochemical screening}

Alkaloids (Alc), flavonoids (Flav), anthocyanins (Ant), quinones (Qun), saponins (Sap), tannins (Tan), steroids (Ste) and terpenoids (Ter) were investigated in leaf powders (F), stems (T) or their bark (ET) and root bark (ER) (Table 1).

Table 1 Chemical groups in different organs of species studied

\begin{tabular}{|l|l|l|l|l|l|l|l|l|l|}
\hline \multirow{2}{*}{ Plant specie } & \multirow{2}{*}{ PU } & \multicolumn{7}{|l|}{ Chemical substances group } \\
\cline { 3 - 13 } & & Alc & Flav & Ant & Ste & Sap & Tan & Qun & Ter \\
\hline \multirow{3}{*}{ Cremaspora triflora } & F & + & - & - & + & + & + & - & + \\
\cline { 2 - 13 } & T & + & - & - & + & + & + & - & + \\
\hline \multirow{3}{*}{ Macaranga schweinfurthii } & ER & + & + & + & + & + & + & - & + \\
\cline { 2 - 12 } & ET & - & + & + & + & + & + & - & - \\
\cline { 2 - 11 } & F & + & + & + & + & + & + & - & + \\
\hline
\end{tabular}


Alkaloids, steroids, saponins, tannins, and terpenoids were found in both species studied. Nevertheless, flavonoids and anthocyanins were present in the organs of $M$. schweinfurthii while they have did not identify in $C$. triflora. A total absence of quinones was observed in studied plant species.

\subsection{Extraction and purification of alkaloids}

The alkaloids were extracted with the organic solvent (methanol and dichloromethane) from a basified aqueous phase $[9,28]$ containing the extract of the leaves.

Table 2 Results of total alkaloids extraction.

\begin{tabular}{|l|l|l|l|l|l|l|}
\hline Plant specie & PM (g) & CE (g) & EY (\%) & Aspect & AlcT (g) & T (\%) \\
\hline Cremaspora triflora & 200 & 29.9 & 14.95 & Greenish & 1.46 & 0,73 \\
\hline Macaranga schweinfurthii & 300 & 58.8 & 19.60 & Greenish & 1.77 & 0.59 \\
\hline
\end{tabular}

After extractions of the alkaloids, it was observed that $M$. schweinfurthii contained $1.77 \mathrm{~g}$ of alkaloids per $300 \mathrm{~g}$ of plant material, i.e. $0.59 \%$ of alkaloids in the leaves used while $C$. triflora contained $1.46 \mathrm{~g}$ of alkaloids per $200 \mathrm{~g}$ of plant material $(0.73 \%$ alkaloids $)$.

The extracted alkaloids were subjected to open column chromatography on a silica gel $60 \mathrm{~F}_{254}$, with AcOEt-MeOH as mobile phase (100: 0, 90:10, 80:20, 70:30, 60:40, 0:100, v/v) coupled to TLC analyses using as mobile phase AcOEt$\mathrm{MeOH}-\mathrm{NH}_{4} \mathrm{OH}$ (90: 9.5: 0.5, v/v/v), and plates were revealed with the reagents of Dragendorff, Wagner, and iodine.

Table 3 Purification of total alkaloids.

\begin{tabular}{|c|c|c|c|c|c|c|c|c|c|}
\hline \multirow{2}{*}{ Plant specie } & \multirow{2}{*}{$\begin{array}{l}\text { AlcT } \\
\text { (g) }\end{array}$} & & \multicolumn{7}{|c|}{ Alkaloid fractions characteristics } \\
\hline & & ID & $\mathrm{m}(\mathrm{g})$ & $\%$ & $\mathrm{Rf}$ & I & W & $\mathrm{D}$ & Obs \\
\hline \multirow{3}{*}{ Cremaspora triflora } & \multirow{3}{*}{1.46} & CT1 & 0.520 & 35,61 & 0.00 & Greenish & Greenish & Dark & - \\
\hline & & $\mathrm{CT} 2$ & 0.934 & 63.97 & 0.52 & Mauve & Red & Orange & + \\
\hline & & СT3 & 0.006 & 0.41 & 0.92 & Mauve & Red & Orange & + \\
\hline \multirow{2}{*}{$\begin{array}{l}\text { Macaranga } \\
\text { schweinfurthii }\end{array}$} & \multirow{2}{*}{1.77} & MS1 & 1.24 & 70.05 & 0.75 & Yellow & Red & Orange & + \\
\hline & & MS2 & 0.53 & 29.94 & 0.80 & Greenish & Greenish & Dark & - \\
\hline
\end{tabular}

Spray reagent (I : Iodine ; W : Wagner ; D : Dragendorrf) ; + : Alkaloid ; - : Other substance; Obs: observation

The fractionation of the total alkaloids yielded 3 fractions from $1.46 \mathrm{~g}$ of total alkaloids of $C$. triflora. These are the CT1 (0.520 g, 35.61\%), CT2 (0.934 g, 63.97\%), and CT3 (0.006 g, 0.41\%). From $1.77 \mathrm{~g}$ of total alkaloids of M. schweinfurthii, two fractions MS1 (1.24 g, 70.05\%), and MS2 (0.53 g, 29.94\%) were obtained. CT2, CT3, and MS1 are alkaloid fractions because they were positive in contact with Dragendorff, and Wagner, two of the six reagents used for alkaloid detection.

\subsection{Evaluation of the antisickling activity in vitro}

Several tests showed that crude plant extracts or solutions of anthocyanins can normalize sickle cells in the blood of a person with sickle cell anemia. To verify this hypothesis, the alkaloid fractions (CT2, and MS1) were subjected to the evaluation of the antisickling activity by Emmel's test (Figure 1a-d, and Table 4). 


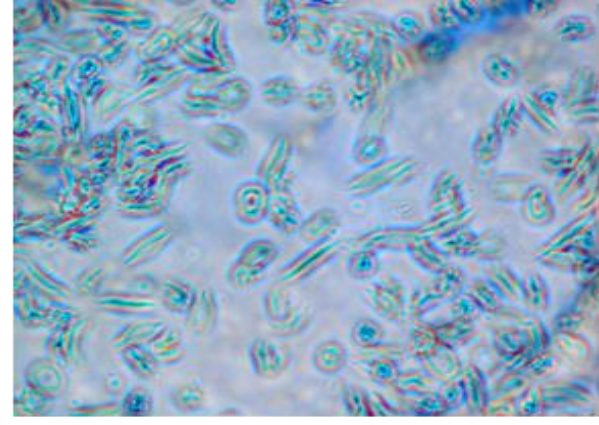

a. Control (Sickle Cell Blood $+\mathrm{NaCl}$ $0.9 \%)$

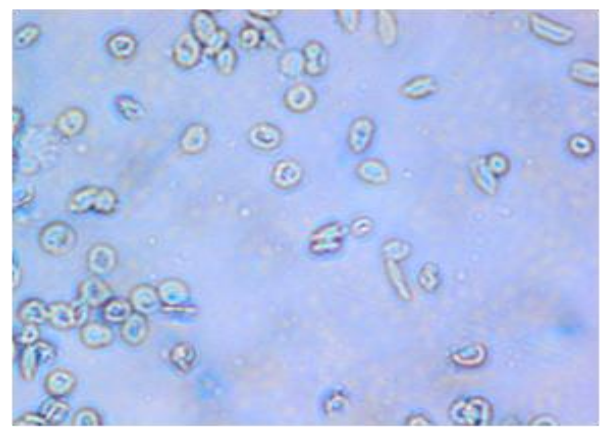

c. SS blood tested with the 0.5 $\mathrm{mg} / \mathrm{ml}$ alkaloid solution

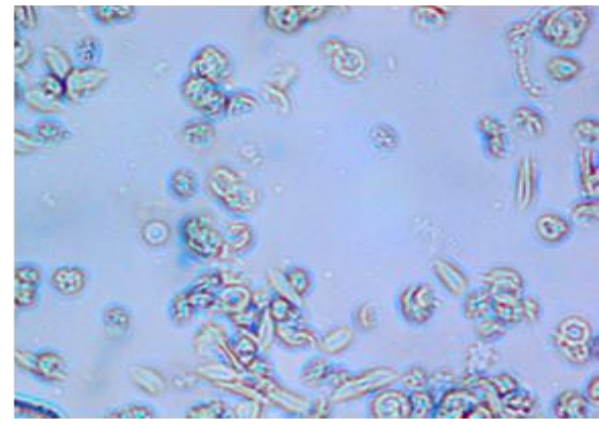

b. SS blood tested with $0.25 \mathrm{mg} / \mathrm{m}$. alkaloid solution

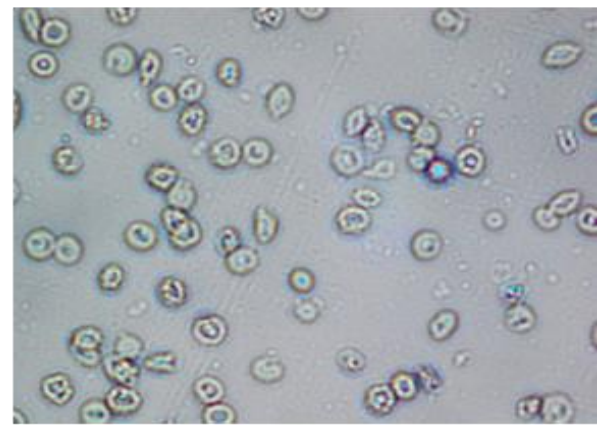

d. SS blood tested with the alkaloid solution at $1 \mathrm{mg} / \mathrm{ml}$

Figure 1 Morphology of sickle cells before (a), and after treatment with C. triflora alkaloidal solution (b-d)

The action of the solutions of the alkaloids showed that these substances had inhibitory activity on sickle cell disease. The sickle cell count before treatment (NSCBT) and after treatment (NSCAT) with the alkaloid solutions was used to calculate the sickle cell inhibition rate (SIR) (Table 4).

Table 4 Results of the biological test.

\begin{tabular}{|c|c|c|c|c|c|}
\hline Plant species & $\begin{array}{l}\text { Purified } \\
\text { alkaloid }\end{array}$ & $\mathrm{C}(\mathrm{mg} / \mathrm{ml})$ & NSCBT & NSCAT & SIR (\%) \\
\hline Control & - & - & 75 & 75 & 0 \\
\hline \multirow{3}{*}{$\begin{array}{l}\text { Cremaspora } \\
\text { triflora }\end{array}$} & \multirow{3}{*}{ СT2 } & 1 & 75 & 7 & 90.66 \\
\hline & & 0.5 & 75 & 46 & 38.66 \\
\hline & & 0.25 & 75 & 48 & 36.00 \\
\hline \multirow{3}{*}{$\begin{array}{l}\text { Macaranga } \\
\text { schweinfurthii }\end{array}$} & \multirow{3}{*}{ MS1 } & 1 & 75 & 50 & 33.33 \\
\hline & & 0.5 & 75 & 58 & 22.66 \\
\hline & & 0.25 & 75 & 72 & 4.00 \\
\hline
\end{tabular}

It appeared that only the alkaloid solution at $1 \mathrm{mg} / \mathrm{ml}$ of Cremaspora triflora gave the sickle cell inhibition rate (SIR) of 90.66\%. Regarding the other solutions, the results showed that at $0.25 \mathrm{mg} / \mathrm{ml}$ the SIR was $36.00 \%$, and at $0.5 \mathrm{mg} / \mathrm{ml}$ the SIR was $38.66 \%$. An inhibition rate of sickling of less than $40 \%$ has been observed. Besides, the alkaloid solutions of Macaranga schweinfurthii showed an inhibition rate of less than $35 \%$ with an almost nill SIR for the $0.25 \mathrm{mg} / \mathrm{ml}$ solution.

These data made it possible to plot the curve of the sickling inhibition rate as a function of the concentration of the solutions of the alkaloids studied (Figure 2) 


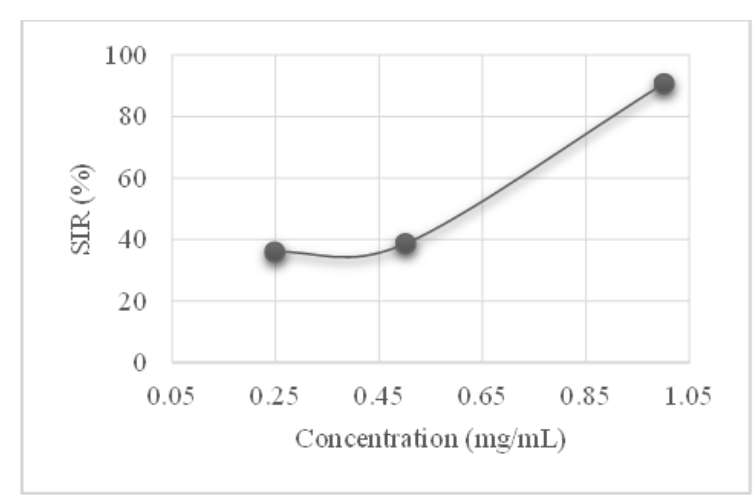

a

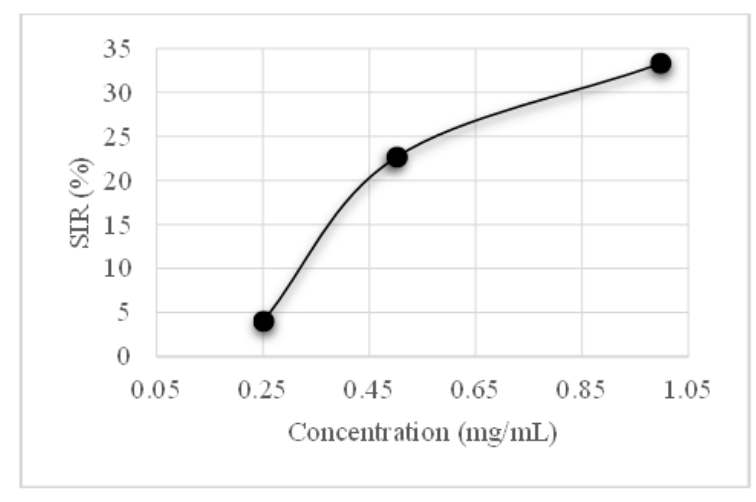

C

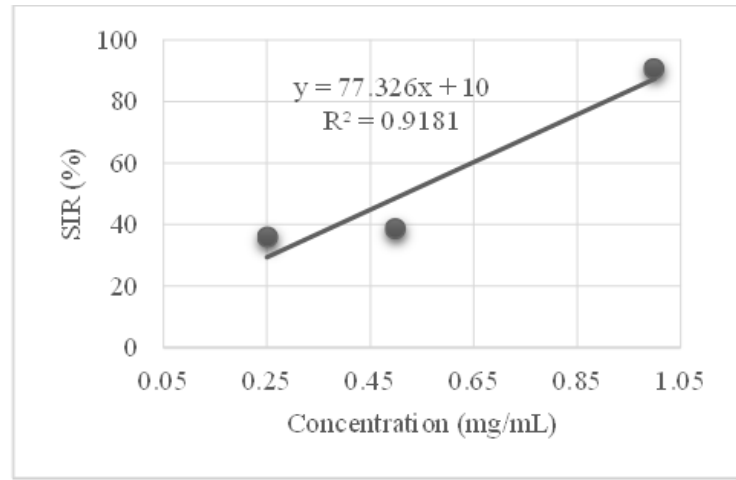

b

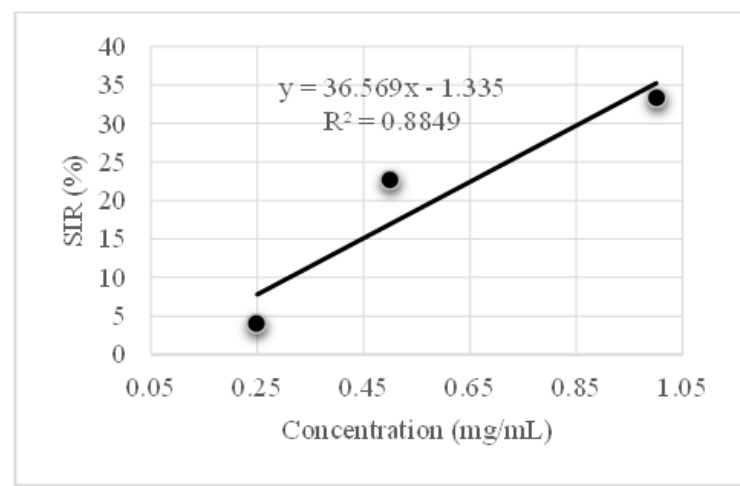

$\mathrm{d}$

Figure 2 Evolution of the SIR and trend curve for alkaloid solutions of C. triflora (a-b) and M. schweinfurthii (c-d).

It appears that the evolution of the inhibition rate as a function of the concentration of alkaloid solutions of $C$. triflora follows an exponential trend while that of $M$. schweinfurthii, a logarithmic trend. The concentration that inhibits the sickling of drepanocytes at $50 \%$ was $0.51 \mathrm{mg} / \mathrm{ml}$ for the alkaloids of $C$. triflora, and $1.40 \mathrm{mg} / \mathrm{ml}$ for the alkaloids of $M$. schweinfurthii.

\section{Discussion}

Alkaloids, steroids, saponins, tannins, terpenoids, flavonoids, and anthocyanins were found in the species studied. These are groups of chemical substances with various biological activities including antibacterial, antifungal, anticancer, antioxidant, antimalarial, antiviral, antidiabetic, and hepatoprotective activities [8, 9, 29]. The presence of polyphenols such as anthocyanins and flavonoids is proof that the species studied contain molecules with the capacity to inhibit sickling in vitro and/or in vivo [9-11, 13, 14].

The total alkaloids content in M. schweinfurthii leaves (0.59\% alkaloids), and C. triflora leaves (0.73\% alkaloids) indicates that these plant species are alkaloidal because a plant is considered alkaloidal when its alkaloid content is greater than or equal to $0.01 \%[29,30]$. Alkaloids were always scarce in plants in general $[29,31]$.

In another study, Mbayo (2019) [29] showed that the alkaloid content of $M$. schweinfurthii was 0.1126\% in leaves and $0.1084 \%$ in stem bark. These contents are less than $0.59 \%$ obtained during the extraction of alkaloids in the leaves of the same species. This discrepancy could be justified by the fact that the content and chemical composition of a plant species depends on the harvest period, the plant age at harvest, the nature of the soil, and other physical and biological characteristics of the plant ecosystem [25].

The evaluation of the antisickling activity by the Emmel method showed that the $C$. triflora alkaloids solutions exhibited the power to normalize the shape of sickle cells with SIR varying between $36.00 \%(0.25 \mathrm{mg} / \mathrm{ml})$, and $90.66 \%$ (1 mg/ml) with an $\mathrm{IC}_{50}$ of $0.51 \mathrm{mg} / \mathrm{ml}$. Besides, the alkaloid solutions of $M$. schweinfurthii showed an inhibition rate of less than 
$35 \%$ with an almost zero SIR for the $0.25 \mathrm{mg} / \mathrm{ml}$ solution, and an $\mathrm{IC}_{50}$ of $1.40 \mathrm{mg} / \mathrm{ml}$. This shows that the $C$. triflora purified alkaloid reacted with a lower $\mathrm{IC}_{50}$ is more active than that of $M$. schweinfurthii $[19,20]$.

This study has just shown that the inhibition of sickling decreases with the decrease in the alkaloid concentration of the solution. In other words, less the solution is concentrated; the weak will be its inhibitory power. The results of inhibiting sickle cell disease at high concentrations could be interesting, but the toxicity of alkaloids may limit their use. Thus, toxicity studies and elucidation of the alkaloid structure of these two plants would allow the lethal dose to be determined, although it was found that they have low antisickling activity.

\section{Conclusion}

The objective of this study was to evaluate the antisickling activity of the total alkaloids of two plants, namely $M$. schweinfurthii and C. triflora. Solutions of the total alkaloid fractions showed an antisickling property which varied with increasing alkaloid concentration. These preliminary results, which corroborate existing data in the literature, would validate the traditional use of these plants in the symptomatic treatment of sickle cell disease. In perspective, the evaluation of the in vivo toxicity of the purified alkaloids and their characterization as well as the evaluation of the antisickling activity of all the purified and characterized alkaloids will be considered.

\section{Compliance with ethical standards}

\section{Acknowledgments}

The authors sincerely thank the Sendwe general reference hospital in Lubumbashi for providing sickle cell blood.

\section{Disclosure of conflict of interest}

The authors declare no competing interests.

\section{References}

[1] Godeau P, Herson S, Piette JC. Traité de médecine, Tome II, Flammarion. Paris. 1987; 509-513.

[2] Gefrier C, Gourbail L, Baudoux S, Dosquet P, Georget M, Pages F. prise en charge de la drépanocytose chez l'enfant et l'adolescencent, Saint Denis la plaine cedex. 2005; 7(16): 23-31.

[3] Mpiana PT, Misakabu FS, Tshibangu DST, Ngbolua KN, Mwanangombo DT. Antisickling Activity and Membrane Stabilizing Effect of Anthocyanins Extracts from Adansonia digitata L. Barks on Sickle Blood Cells. International Blood Research \& Reviews. 2014; 2(5): 198-212.

[4] Kalonda EM, Mbayo MK, Kanangila AB, Muhume SK, Kahambu VZ, Tshisand P, Tshibangu DST, Bongo NG, Ngbolua KN, Lumbu J-BS et Mpiana PT. Evaluation of Antisickling Activity of Some Insect Extracts from Katanga in Democratic Republic of the Congo. J. of Advancement in Medical and Life Sciences. 2015; V3I1.

[5] Tula Y. Activité antidrépanocytaire et stabilité physico-chimique des anthocyanes extraits des bulbes de Hypoxis angustifolia et des feuilles de Ipomoea batatas, mémoire UNIKIN, www. Mémoire on line.com/11/13/8094/activité-anti-drépanocytaire-et stabilité-physico-chimique-des-anthocyanes-extraitsdes bulbes-d.html. 2012.

[6] Ngbolua KN, Mudogo V, Mpiana PT, Malekani MJ, Rafatro Herintsoa, Urverg Ratsimamanga U, Takoy L, Rakotoarimana H, Tshibangu DST. Evaluation de l'activité anti-drépanocytaire et antipaludique de quelques taxons végétaux de la République démocratique du Congo et de Madagascar. Ethnopharmacologia. 2013; 50: 1924.

[7] Mpiana PT, Ngbolua K.N, Tshibangu DST. Les alicaments et la drépanocytose : une mini-revue. C. R. Chimie 19. 2016; 884-889.

[8] Hostettmann K, Marston A. Twenty years of research into medicinal plants: Results and perspectives; Phytochemistry. 2002; 1: 275-285.

[9] Bruneton J. Pharmacognosie: Phytochimie et plantes médicinales. 3e édition. TEC. Paris. 2009; 144-145, 196, 274-388, 656,783-1085, 1191. 
[10] Mpiana PT, Mudogo V, Ngbolwa KN, Tshibangu DST, Shetonde OM, Mbala MB. In vitro antisickling activity of anthocyanins from Ocimum basilicum L. (Lamiaceae). Int. J. Pharmacol. 2007a; 3(4): 371-374.

[11] Mpiana PT, Mudogo V, Tshibangu DST, Ngbolwa KN, Shetonde OM, Mangwala KP, Mavakala BK. In vitro antisickling activity of anthocyanins extracts of a Congolese Plant: Alchornea cordifolia M Arg. J. Med. Sci. 2007b; 7(7): 1182-1186.

[12] Mpiana PT, Mudogo V, Tshibangu DST, Ngbolua KN, Tshilanda DD, Atibu EK. Antisickling Activity of Anthocyanins of Jatropha curcas L. Chemistry and Medicinal Value. 2009; 25: 101-108.

[13] Mpiana PT, Makelele LK, Oleko RW, Bokota MT, Tshibangu DST, Ngbolua KN, Mbala MB, Atibu EK, Nshimba SM. Antisickling Activity of Medicinal Plants Used in the Management of Sickle Cell Disease in the Tshopo District, DR Congo. Australian Journal of Medical Herbalism. 2010; 22(4): 132-137.

[14] Mpiana PT, Tshilanda DD, Onyamboko DV, Mwanangombo DT, Tsalu PV, Misengabu NK, Tshibangu DST, Ngbolua KN. In vitro Antisickling Activity of Anthocyanins from Ocimum canun (Lamiaceae). J. of Advancement in Medical and Life Sciences. V3I2. 2015.

[15] Tshibangu DST, Shode FO, Koobanally N, Mudogo V, Mpiana PT, Ngbolua KN. Antisickling triterpenoids from Callistemon viminalis, Meulaleuca bracteata var. Revolution Gold, Syzygium guineense and Syzygium cordatum. The 14th NAPRECA Symposium and AAMPS Ethnoveterinary Medicine Symposium, 8th-12th August. International Center For Insect Physiology and Ecology (ICIPE): Kasarani, Nairobi, Kenya. 2011; 296-300.

[16] Ahmedou BF. Contribution à l'étude de l'activité antidrépanocytaire d'un limonoïde réarrangé de l'extrait de Khaya senegalensis (Desr) A. Juss et du cromoglycate disodique. Thèse de doctorat en Sciences Pharmaceutiques, Université Libre de Bruxelles, Bruxelles. 2000.

[17] Sato T, Ohnishi ST. In vitro anti-sickling effect of cepharanthine. European J. Pharmacol. 1982; 83: 91-95.

[18] Kanangila BA. Etude chimique et activité antifalcémiante des plantes utilisées traditionnellement contre la drépanocytose à Lubumbashi/RD Congo, Thèse présentée en vue de l'obtention du grade de Docteur en Sciences chimiques, Université de Lubumbashi. 2018: 1-150.

[19] Ngbolua KTN, Ngunde-te-Ngunde S, Tshidibi DJ, Lengbiye ME, Mpiana PT, Ekutsu EG, Munene JJMM, Gbolo ZB, Bongo NG, Nzemu G. Antisickling and antibacterial of extract from a Congolese Diplopod (Tachypodoiulus sp, Arthropoda). J. of Advanced Botany and Zoology. 2014a ; V1I3.

[20] Ngbolua KTN, Bishola TT, Mpiana PT, Mudogo V, Tshibangu DST, Ngombe KN, Ekutsu EG, Gbolo BZ, Ngandu OK. Ethno-Pharmacological Survey, In Vitro Anti-Sickling and Free Radical Scavenging Activities of Carapa procera DC. Stem Bark (Meliaceae). Nova Journal of Medical and Biological Sciences. 2014b; 2(2): 1-14.

[21] Mpiana PT, Ngbolua KN, Mudogo V, Tshibangu DST, Atibu EK, Tshilanda DD, Misengabu NM. Anti-Sickle Erythrocytes Haemolysis Properties and Inhibitory Effect of Anthocyanins Extracts of Trema orientalis (Ulmaceae) on the Aggregation of Human Deoxyhemoglobin S in Vitro," Journal of Medical Sciences. 2011; 11(3): 129-137.

[22] Lumbu S, Mbayo K, Kahumba B. Analyse semi-quantitaive de quelques plantes utilisées en médecine traditionnelle à Lubumbashi et ses environs. Ann. Méd.Vét. PUL. 2005a; XVII(1): 8-12.

[23] Lumbu S, Kahumba B, Kahambwe T, Mbayo K, Kalonda M, Mwamba M, Penge O. Contribution à l'étude de quelques plantes médicinales antidiarrhéiques en usage dans la ville de Lubumbashi et ses environs. Ann.de Pharmacie. 2005b; 3(1): 75-86.

[24] Liu WJH. Traditionnal Herbal Medecine Research Method. John Wiley \& Sons. 2011; 448.

[25] Mbayo M, Kalonda E, Kalunga R, Tshisand P, Kanangila A, Mwamba F, Bakari S, Kahumba J, Lumbu J-B. Test antimitotic activity and Preliminary Chemical study of some Euphorbiaceae of the southern Katanga. Phytothérapie. 2016; 1-13.

[26] Mbuyi K S, Kalunga M, Cimanga CC, Numbi I, Mbayo K, Ali K, Kabadi K, Mwamba M, Kalonda M, Lumbu S. Chemical screening of some reputed anti-malarial plants Used in Lubumbashi city and its surroundings. PhytoChem \& BioSub Journal. 2018; 12(3): 160-170.

[27] Maloba MJ, Muyumba NW, Kasanya KJ, Mutombo SC, Mbayo KM, Ngoy KE, Lumbu SJ-B. Ethnobotanical survey and preliminary chemical screening of 14 plants reputed antigastritis in Lubumbashi and surroundings (DR Congo). IEEE-SEM. 2020; 8(12): 62-69. 
[28] Lumbu S. Buchnerdine et Buchneridine, nouveaux alcaloïdes dérivés de la spermine ; structure et synthèse totale; thèse présentée en vue de l'obtention du grade de docteur en sciences ; Université Libre de Bruxelles ; Faculté des sciences ; Service de Chimie organique. 1992.

[29] Mbayo KM. Identification et évaluation de l'activité anticancéreuse de la triacanthine isolée de Bridelia duvigneaudii J. Léonard (Phyllanthaceae). Thèse en chimie organique, Département de chimie, Faculté des sciences Université de Lubumbashi. 2019.

[30] Hegnauer R. Biochemistry, distribution and taxonomic relevance of higher plant alkaloids. Phytochemistry. 1988; 27: 2423-2427.

[31] Milcent R, Chau F. Chimie organique hétérocyclique: Structures fondamentales-Chimie et Biochimie des principaux composés naturels. EDP Sciences. Paris. 2003; 635: 725-811. 